\title{
The Firstborn Laestadians and the sacraments
}

Conceptual analysis as an approach to answering the question of why the Firstborn in Finland began administering the sacraments

F irstborn Laestadians ${ }^{1}$ represent one branch of the Laestadian revival movement following the so-called Great Division of around the turn of the twentieth century. This article examines two concepts; 'the priesthood of all believers' and 'the preacher', which are used by adherents of Firstborn Laestadianism (FBL) to elucidate the further schism which took place in 2014-16 between the Firstborn and the Evangelical Lutheran Church of Finland (ELCF). Both concepts are to some extent contrasted with comparable ideas in Martin Luther's (14831546) and Lars Levi Laestadius's (1800-61) thinking, because Luther and Laestadius are held in high esteem by the Firstborn.

\section{Introduction}

Since the middle of the nineteenth century, Laestadians in Finland have traditionally had an official connection as members of the Evangelical Lutheran Church of Finland (ELCF). Thus, ELCF's ministers baptise Laestadian children, and Laestadians partake in the Holy Communion administered by the ELCF (Talonen 2014: 26).

1 In this article two forms are used when referring to Firstborn Laestadians. 'Firstborn Laestadianism', abbreviated 'FBL', refers to the belief system. 'Firstborn' and 'Firstborn Laestadians' are synonymous and refer to the collective group that are adherents of FBL.
This set-up changed in the twenty-first century when, between 2000-1, Firstborn Laestadians in Sweden and Norway started administering the sacraments on their own (Talonen 2016: 141). In Finland, an historic moment took place on 5 December 2015 as Firstborn (lay) preachers in the city of Mikkeli led the celebration of the Lord's Supper in the local prayer house (Rytkönen 2015a: 6-7; Hytönen and Sorsa 2016: 2489). This contravened several regulations of the ELCF: the Lord's Supper is to be celebrated on a regular basis in the local church and otherwise by the permission of the local vicar, but above all, it is to be administered by an ordained pastor (KL 5:1; KJ 2:9, 12, 13). Similar arrangements started to take place also in other cities, and later the Firstborn in Finland started to practise (lay) baptisms (Rauhan Side, 3, 2016: 12; Rytkönen 2016a; Berg 2016).

Not all of FBL's followers in Finland endorsed this new step. The Firstborn in Finland split in August 2016 when a faction formed the Esikoiset Association and announced its status as a movement within the ELCF (Rytkönen 2016c; Kettunen 2017: 273-4). The 'Esikoiset ry' Association had approximately 1500 members in 2017, and they gathered in ELCF facilities (Airikka 2017). In 2016, the majority of 
FBL's adherents in Finland associated themselves with the organisation called Esikoislestadiolaiset, which is the faction of Firstborn Laestadians that started administering the sacraments. But they did not resign their membership of the ELCF (Berg 2016; Rytkönen 2016b, 2016c). Esikoislestadiolaiset retained control of the prayer houses after the division because the association owned the buildings. Why did Firstborn Laestadians change a 150-yearold practice by administering the sacraments on their own? Apparently, this development has several aspects to it, but in this article, I shall focus on theological doctrine.

The current (academic) research concerning Laestadianism is extensive (Snellman 2011: 11-17; Palola 2014: 23-7; Nordvik 2015: 9-17). Finnish theological research specialising in Church history has a long tradition of researching revival movements. A great deal of this research concerns Laestadianism - primarily its largest branch, called Conservative Laestadianism (Huhta 2001: 23-30). Many current studies in Finland of Conservative Laestadians have been written from a sociological perspective (e.g. Hurtig 2013; Hintsala and Kinnunen 2013; Linjakumpu 2018). Apart from two articles by Torgeir Nordvik (2013a, 2013b), which deal with the Firstborn's progress in Sweden and Norway towards administration of the sacraments, Firstborn Laestadians have drawn little attention in current research both in Finland and internationally.

In addition to Nordvik's articles, some research conducted in Norway has mainly or partly focused on Firstborn Laestadians (e.g. Sivertsen 1955; Aadnanes 1986; Bolle 2000). Studies of the Firstborn (in Finland) have mainly been carried out in the field of Church history. Aulis Zidbäck (1941: 25764) initiated this work in his book about the Laestadian lay preacher Juhani Raattamaa
(1811-99). Foremost in later research on Firstborn Laestadians in Finland are Antti Lahtinen's (1984) master's thesis about the development of the Firstborn up until 1911, Pekka Raittila's (1984) article concerning the history of the Firstborn in Finland, and finally an extensive section in Seppo Lohi's (2007: 139-280) book about the Great Division in the Laestadian revival movement.

Some other relevant inquiries about the Firstborn in Finland should be listed, such as Jouko Talonen's (1993) book concerning the Firstborn's role in Finnish society in the years 1911-44, Markku Ihonen's (2001) article about the Firstborn's challenges in modern Finnish society and Leena Numminen's (2000) master's thesis about gender roles within the Firstborn. The second and least researched subject concerns FBL's doctrinal accents. This approach is primary in Risto Blom's (2001) survey on the concept of rebirth, as well as, Ville Kettunen's (2016) master's thesis about the preacher Sam Wettainen and his proclamation. Kettunen (2017) has also described the schism between Firstborn Laestadians and the ELCF in a brief article.

Currently, an up-to-date and precise description of the Firstborn in Finland does not exist, since the split was so recent. Most facts in this article about the Firstborn were collected before the split of 2016; however, this does not mean that they are totally irrelevant.

My purpose in this article is to investigate two concepts in FBL: that of 'the priesthood of all believers' and that of 'the preacher'. The former is highly relevant since it occurs in arguments for the administering of sacraments by Firstborn Laestadians, and furthermore, this concept is essential for Luther and in Lutheran theology, concerning what the Church is and expressing the relation between lay people 


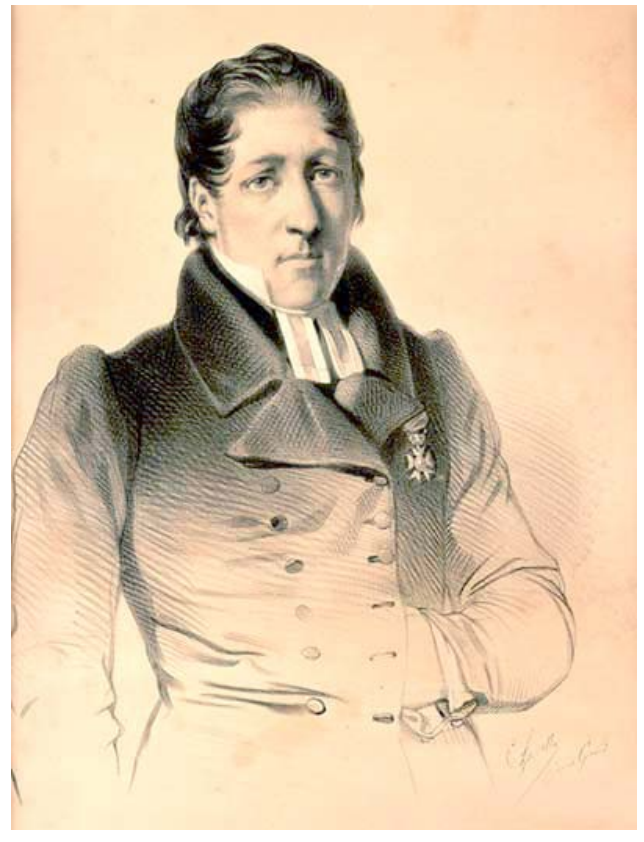

Lars Levi Læstadius (1800-1861). Voyages en Scandinavie et Laponie, 1839.

and the office of the ministry (Gassmann and Hendrix 1999: 124, 133; Smith 2000: 48-61).

The concept of the preacher is surprisingly complicated to define well. In Finnish, the word for preacher is saarnaaja and that is common parlance within Laestadianism for a man, commonly a lay person, who is functioning as a speaker (Hintsala and Kinnunen 2013: 38-42). However, the term 'preacher' can occasionally refer to an ordained Laestadian pastor. I am also aware of the concept sanan palvelija (servant of the word), which among the Firstborn refers, in a narrow sense, both to a preacher or a leading preacher, called a lähetysmies (Kettunen 2017: 272; Raudaskoski 2014b). Still, this distinction is not complete since the general sense of preacher includes leading preachers. In this article, I focus on 'preacher' as general term for a speaker, who typically is a lay person.

I will show that the concepts of 'the priesthood of all believers' and of 'the preacher' can shed light on why preachers broke with a long tradition when they began to administer the sacraments by themselves. I will also compare and contrast Martin Luther's (1483-1546) and Lars Levi Laestadius's (1800-61) understanding of the same concepts. I will also consider the lay preachers Juhani Raattamaa and Joonas Purnu (1829-1902) who are also respected in FBL (Talonen 1993: 12-18), but not as highly as Luther and Laestadius.

The sources in this article are manifold. The main publication of the Esikoislestadiolaiset Association, Rauhan Side (Bond of peace), published four times annually, is one important source in the current article. Specifically I consider the numbers from the years 1990-2016, including leading articles, sermons and letters called lähetyskirjeitä (mission letters). Firstborn Laestadians in Finland have also published several books. Isän ääni (The Father's voice), produced in three volumes between 1960 and 1989, is the Finnish translation of selected material from the Swedish journal Fadersrösten, edited by the preacher Sam Wettainen. Vanhinten kirja (The Elders book), a volume published in four parts from 1979-90, contains mission letters (lähetyskirjeitä). In 1996-2000 the Firstborn in Finland published Laestadius's sermons in three volumes entitled Saarnat (Sermons). Regarding Isän ääni, I refer to Ville Kettunen (2016), but because of the large extent of both Vanhinten kirja and Laestadius's sermons, they are beyond the limitations of this article. Secondary sources in this article include published interviews, letters, magazines and journals, whereas the literature consists of dissertations and (academic) articles concerning the Firstborn, Laestadianism in general, Laestadius himself and Martin Luther.

Gerd Snellman's dissertation Sions 
döttrar (Zion's daughters, 2011) deals with, among other things, what the tradition is and how Laestadian women have been involved in its transmission. Even though Snellman considers a different target group and a different branch of the Laestadian revival (called Rauhan Sana, Word of Peace), I find some of her theoretical considerations applicable to this study, since the transmission of tradition is also important for the Firstborn.

Snellman says in Sions döttrar (2011: 17-19) that a tradition creates and maintains an identity and gives a certain group its character, that it has a content, an aim as to why it is transmitted and it is actively and consciously transmitted. This is applicable in FBL. According to the regulations of the Esikoislestadiolaiset Association, its activity is based 'solely on the Holy Bible and Luther's doctrine'2. Furthermore, from the Firstborn's very beginnings, the movement has wanted to treasure the original legacy of Laestadianism and be loyal to Laestadius's teachings (Airamo and Leivo 1983: 7; Blom 2001: 10-11). That is to say, the Firstborn transmit and want to maintain a certain tradition. In this article, following Snellman (2011: 18-19), my focus is on the content of the tradition that is transmitted. The instrument used to communicate this tradition is printed text, which to some extent has originated from an oral form (e.g. sermons).

Since the sources are texts, my choice of method is textual analysis; namely an

2 Esikoislestadiolaiset ry, $2 \$$ Yhdistyksen tarkoitus. I called up the regulations of the Esikoislestadiolaiset Association on the website of the Finnish Patent and Registration Office. According to Risto Blom, during $1922-70$ the expression 'Luther's doctrine' referred to The Lutheran Confessions, that is to say, The Book of Concord (Blom 2001: 10-11, fn 3 and 4). analysis of expressed ideas on the concepts of 'the priesthood of all believers' and 'the preacher'. Carl-Henric Grenholm (2006: 213-14) says that the purpose of this method is to describe and elucidate expressed ideas and arguments, as well as to discuss the reasonableness of the ideas. In the case of the latter, I consider FBL's interpretations in relation to Luther and Laestadius's thinking.

All translations in this article are my own, and therefore I am responsible for them.

\section{Firstborn Laestadians in Finland}

Laestadianism originated in $1845^{-6}$ due to the preaching of Lars Levi Laestadius, who served as a vicar in the Church of Sweden, first in Karesuando's congregation and later in Pajala. In the space of only one decade the revival had spread to the North Calotte in Scandinavia (Talonen 2013: 47; Talonen 2014: 19-23).

The growth of the revival was especially powerful in 1870-80 (Talonen 2013: 47; see further Lohi 1997). In the late 1860 s, Laestadianism reached Helsinki, and during the 1870 s, it spread to many cities in southern Finland and the Satakunta, Karelia, Central Finland and Häme regions. The highest concentration of Laestadians in Finland is to be found in an area of land from Lapland to Central Ostrobothnia (Talonen 2014: 23). Laestadianism spread all the way to the USA in the 1860 s and continued to expand across the new continent during the following decade (Palola 2014: 30-7). In the 1870s, Laestadianism reached Saint Petersburg and proceeded to Tallinn in the 189os (Talonen 2013: 47, 49; Talonen 2014: 23-4).

Pekka Raittila argues that the Great Division at the end of the nineteenth century was caused by this rapid and widespread expansion and also the shift to a 
new generation of leaders in Laestadianism (Raittila 1984: 190; see further Lohi 2007). The Great Division resulted in the founding of three Laestadian groups, the first being the Firstborn Laestadians, led by preachers from Swedish Lapland who wanted to cherish the original tradition from the beginning of the revival (Raittila 1984: 191-5; Talonen 2014: 26). The Firstborn's activity in Finland began in 1902-3 after preachers from Swedish Lapland returned from southern Finland (Raittila 1984: 198-200; Talonen 2014: 26). The second Laestadian group was the New Awakening, which was located near Kittilä who wanted to restore Laestadius's pietistic legacy, that is, an emphasis on the individual's inner experience (Raittila 1984: 203; Talonen 2014: 26-7). The third and largest group after the Great Division was the Conservative Laestadians, who neither accepted the authority of the preachers from Swedish Lapland nor gave in to the expressed demands of renewal by the New Awakening (Talonen 2014: 27).

Laestadianism is an international revival movement, and Laestadius's sermons have been published in numerous languages including Finnish, Swedish, Sami, Norwegian, English, German, Russian, Estonian and Latvian (Talonen 2013: 47). In 2016, Firstborn Laestadian influence stretched from Norway to Finland to the Baltic countries, Russia, the USA and also Canada (Talonen 2014: 31; Talonen 2016: 134). The Firstborn arranged small meetings in Central Europe including Germany, the Netherlands and Belgium by sending preachers once or twice a year from the late 1970s (Talonen 2000a: 41; Talonen 200ob: 56; Rauhan Side, 31(4), 2009: 14). The Esikoiset Association took over the work in Germany and Netherlands after the Firstborn's division in 2016 (Airikka 2017).

Firstborn Laestadianism had approximately 31,000 supporters in 2016. Finland

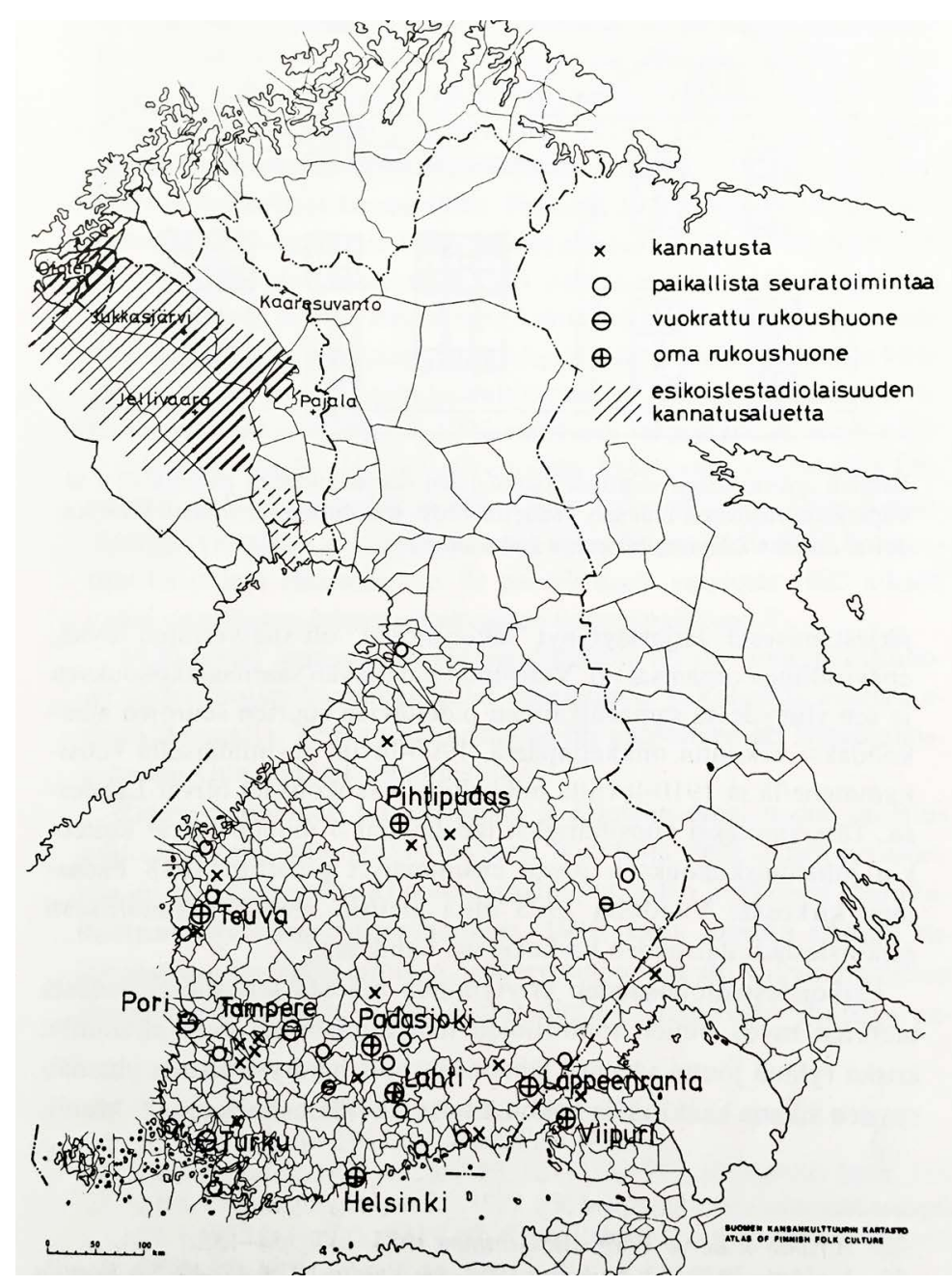

Advocacy and activity centers of Firstborn Laestadianism in Finland until 1910 (regarding prayer houses until 1917). x = advocacy of Firstborn Laestadians, $\mathrm{O}=$ local devotional services activities, $\Theta=$ rented prayer house, $\Theta=$ prayer house owned by the congregation, /// = advocacy of Firstborn Laestadianism. Map by Seppo Leivo. Talonen 1993: 27. 
and the USA (where it was established as the Old Apostolic Lutheran Church, OALC) represented a clear majority of that population with 12,000 and 14,000 members respectively (Talonen 2016: 134, 142). According to Blom (2001: 14), in the year 2000, Sweden had roughly 1,000 adherents and Norway a couple of thousand. FBL's most significant sphere of influence in Finland, from the time it was formed to this day, is the region of Häme, especially the city of Lahti. Furthermore, Firstborn areas with supporters includes cities such as Turku, Tampere and Helsinki, along with the region of North Karelia (Raittila 1984: 198-216; Talonen 1993: 22-6, 80-2; Ihonen 2001: 161). In the beginning of the twentyfirst century, the Firstborn in Finland had 120-150 preachers and owned 24 prayer houses (Blom 2001: 15; Ihonen 2001: 169).

According to the brochure Usko on sydämen asia (Faith is a matter of the heart, 2014: 5), the Firstborn in Finland organise seurat (devotional services) in local prayer houses, homes and churches, but in some places their activities consist of, for example, youth evenings, bible studies and social work. The Firstborn in Finland also have isot seurat (large devotional services), gathering supporters from wide areas. The Firstborn's main annual events are during Midsummer in Lahti and in Gällivare in Sweden at Christmas, whereas larger meetings in the Firstborn's own prayer houses in Finland are arranged three or four times yearly (Talonen 1993: 28; Blom 2001: 15). According to Usko on sydämen asia (2014: 10), a regular meeting consists of hymns, prayers and readings from a book of homilies; however, the main element is the preacher's sermon. Almost since the founding of Firstborn Laestadianism, Laestadius's sermons have regularly been read aloud at its gatherings (Talonen 1993: 12; Ihonen 2001: 169, 171; Talonen 2016: 14).

\section{Firstborn Laestadianism in Finland} and the priesthood of all believers

The first concept that I will examine is the Firstborn's interpretation of 'the priesthood of all believers', also known as 'the common priesthood' or 'the general priesthood. In Lutheran theology, the Church is not based on hierarchy, and it is not primarily an institution. The Church is rather 'a living community of people in Christ', and the priesthood of 'all baptized believers' forms this community (Gassmann and Hendrix 1999: 133). Here, I shall present five examples of thoughts expressed on the priesthood of all believers within Firstborn Laestadianism.

Firstly, in December 2015 in a sermon given at the local prayer house in Mikkeli, the preacher Raimo Haimilahti claimed that Firstborn Laestadians represent 'the true believers, who have the Holy Spirit in their hearts' (quote from Rytkönen 2015a: 7). The same preacher referred to the Book of Revelation (probably 1:6 or 5:10), saying that Christ 'has made us kings and priests' and ' $[t]$ his is the priesthood he instituted' (quote from Rytkönen 2015a: 7). In his sermon, Haimilahti claimed that the official ministers are not real priests, and there is no other priesthood, priest or true minister besides the priesthood of believers, which is represented only by the Firstborn. With regards to what happened in Mikkeli and Haimilahti's argument, the concept of a priesthood of all believers was used to justify the administering of sacraments by Firstborn preachers who were neither ordained nor authorised by the ELCF.

Secondly, in another sermon given in December 2015, although this time at the Firstborn's large meeting in Gällivare, the preacher Odd Minde said that the Eucharist may be administered by those elected from 'the common priesthood' or 'the royal priesthood' (Minde 2016), which 


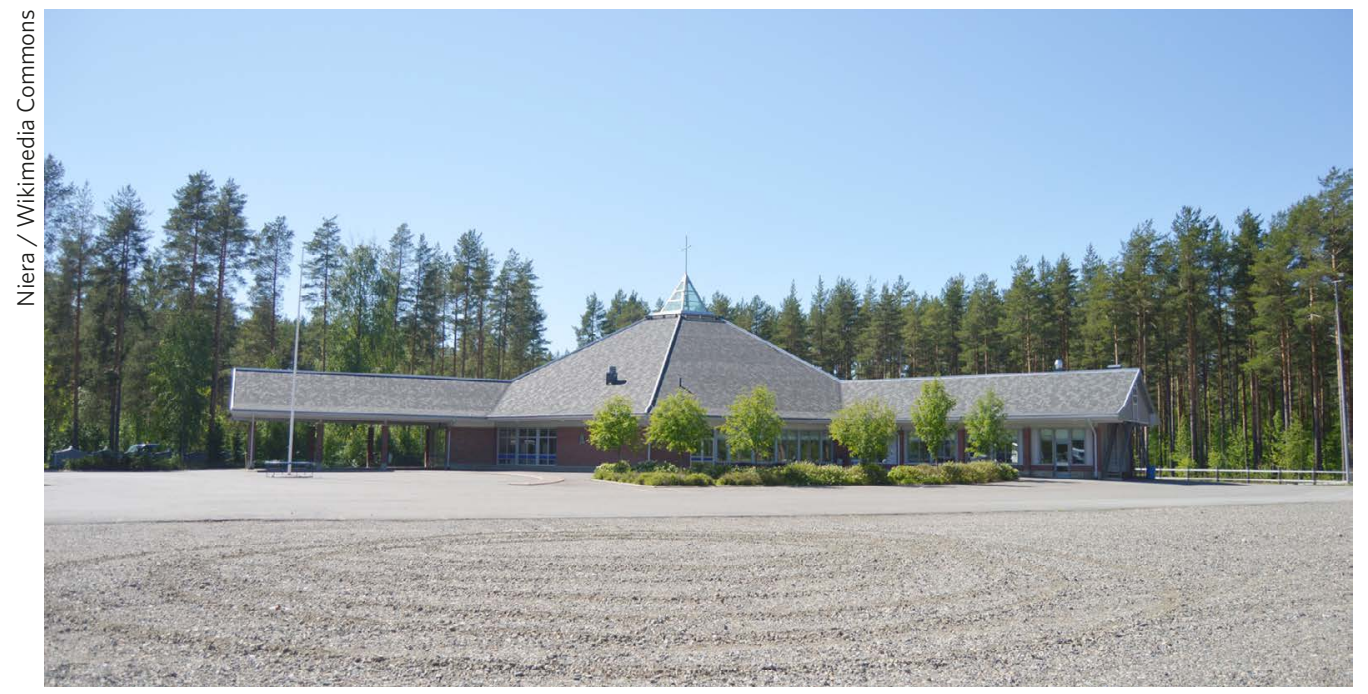

Firstborn Laestadian prayer house in Joensuu, Eastern Finland.

according to Minde supported the administration of sacraments by lay persons. Minde also insisted that Luther, in his letter to the Bohemian brothers, had written that the father of the family could distribute the Lord's Supper. In these two cases, both at very important events, the priesthood of all believers was explicitly used to justify the administering of the Lord's Supper among the Firstborn. Haimilahti and Minde's sermons raise some questions about the interpretation of the concept of the priesthood of all believers. Do Firstborn Laestadians deny the existence of the office of the ministry? Is a member of the priesthood of all believers, as a priest, at the same time a minister? That is to say; is there any distinction between the priesthood of all believers and the office of the ministry? These questions urge further research for more expressions within FBL concerning the priesthood of all believers.

Similar examples of the notion occur in Firstborn Laestadian publications, but they are rare. The preacher Sam Wettainen may serve as a third example. In the 1980 s he claimed in Isän ääni that lay persons functioning as preachers participate in the office of the ministry, saarnavirka (quote from Kettunen 2016: 83), whereas every Christian by rebirth participates in a royal priesthood and possesses the power of the keys (Kettunen 2016: 83-4). Two more examples occurred in Rauhan Side. In one sermon published in 1998, Matti Aaltonen preached that in the New Covenant " the believers" in Jesus, that is to say, God's children... [are] the Lord's priests' (Aaltonen 1998: 7). According to Aaltonen (1998: 7-9), both men and women are actually priests and partake in the mission to spread the gospel and as priests 'we all have the right and permission' (p. 9) to declare the absolution of sins. In another sermon, originally from 1977, but published in 2009, the preacher Eino Nousiainen said with reference to 1 Peter 2:9 that every believer occupies a position called pappisvirka (Nousiainen 2009: 6), which seems equivalent to the office of the ministry.

To sum up, in four of the five examples, the main idea of the priesthood of all believers is the same: all true believers are priests by rebirth. In three of the five examples, the priesthood of all believers means that every believer is authorised with the power of the 
keys. From these five examples it is difficult to point to a clear consensus in FBL, however, the concept of the priesthood of all believers implies that the true believers are the genuine priests. According to Haimilahti, the only existing priesthood is the priesthood of all believers. Minde and Nousiainen and perhaps also Aaltonen seem to be in line with Haimilahti's emphasis, in which no essential distinction is made between the priesthood of all believers and the office of the ministry. Wettainen seems to maintain a minor distinction between the priesthood of all believers and the office of the ministry, but at the same time, he also says that preachers participate in the office of the ministry. It is unclear if the preacher by participation in the office of the ministry has limited jurisdictions, that is, merely the right to preach and absolve, but not to administer the sacraments.

Another important aspect of FBL is the principle that the priesthood of all believers and the power of the keys are linked to the movement's ecclesiology. John 20:19-23 is used as a central Bible passage in two leading articles in Rauhan Side. According to Pekka Liuksala (1996: 2), Jesus established the congregation of the New Covenant and gave the disciples the power of the keys. In 2012 Raimo Airamo wrote that the power to bind and forgive sins belongs to 'all reborn Christians' (Airamo 2012: 2); that is to say, Christians with a living faith that are Jesus' true disciples and who constitute his congregation (Airamo 2012: 2; see also Airamo 2007: 2). One more sermon published in Rauhan Side in 2012 touched upon the power of the keys. According to the preacher Lars Larsson, the power of the keys belongs to 'God's congregation' and 'these keys are still used in living Christianity' (Larsson 2012: 8; see also Larsson 2016: 6-8). Both Airamo and Larsson referred directly to the
Firstborn and thus emphasised the movement's exclusivity, which is typical of FBL (Blom 2001: 54-7; Kettunen 2016: 77-87).

The aforementioned ecclesiology, connected to FBL's understanding of the power of the keys, was typical in Firstborn sermons, letters and published material from the 1980 os to the beginning of the twentyfirst century (Blom 2001: 53-6, 63; Kettunen 2016: 77-87). One way to explain Firstborn Laestadianism's ecclesiology is by looking into its historical background. Around the middle of the nineteenth century, Raattamaa started to absolve followers of their sins with Laestadius's permission. Both men understood that this right - to declare forgiveness or to bind one to his sins - belongs to every reborn Christian and not primarily to the clergy (Leivo 2001: 109-20). At the same time, Raattamaa denied that a priest or minister, who is not born anew, can effectively absolve sins (Blom 2001: 39). Thus, absolution by lay persons in the Laestadian revival practically became the new norm. When this sense of the power of the keys was combined with the idea of Laestadians forming the congregation of true believers, it gave characteristics to the Laestadian movement that caused tensions in the twentieth century with the ELCF and its priests (Talonen 2014: 22-3).

Some differences are apparent when comparing the tenets of the Firstborn to those of Luther and Laestadius. To begin with, Laestadius did not mean that the clergy's keys are not effective at all; rather, he criticised the clergy for not using them apart from their ordinary work (Juntunen 1982: 166-80). In addition, FBL's interpretation of the priesthood of all believers and the power of the keys is affirmed, but also denied by Luther. In the tract Address to the Christian Nobility of 1520 , Luther says that the priesthood of all believers is 
based on baptism, the gospel, and faith, but that the proper initiation to this priesthood is through baptism by water (Lieberg 1962: 40-50; Stein 1974: 66-7; Lohse 1995: 306-11; Smith 2000: 49-55). On other occasions, Luther emphasises participation in this priesthood (by faith) through Jesus Christ (Lieberg 1962: 47-50, 69-74; Öberg 1984: 63-4; Lohse 1995: 306, 312). However, in for example, On the Councils and the Church, dated 1539, Luther writes that Jesus Christ instituted the office of the ministry as the fifth distinguishing mark of the Church with responsibility (in private and in public) for marks 1-4 of the Church, that is; teaching God's word, baptism, the Lord's Supper and the keys (Lieberg 1962: 69-74; Öberg 1984: 63-4; Lohse 1995: $306,312)$. The keys belong to everyone in the priesthood of believers as well as the whole congregation of the Church, but the individual's proper use of the keys is limited to emergencies and the private sphere (Lieberg 1962: 58-9; Stein 1974: 68-70, $82-3$ ). That is to say, according to Luther, a member of the priesthood of believers (a lay person) neither has the right to declare absolution, baptise or administer the Lord's Supper publicly, nor is it to be the standard practice in the Church, since these tasks belong to the office of the ministry.

\section{Firstborn Laestadianism in Finland and the concept of the preacher}

The second concept that I will study in this article is FBL's interpretation of the notion of the preacher. I will point out a number of different aspects connected to this concept since each of them sheds light upon the question why the Firstborn in Finland began administering the sacraments.

The Firstborn Laestadian movement mainly consists of lay persons, and only a few ordained ministers have served as speakers during the movement's history
(Talonen 2016: 142). In 2000, five ministers from the ELCF were active within the Firstborn in Finland (Talonen 2000a: 40). Since lay preacher Joonas Purnu's days, the ideal in FBL seems to have been that the preachers should have no theological education (Kettunen 2017: 272-3; Blom 2001: 130).

To become a preacher, one must first occupy the position of a reader; that is, reading Laestadius's sermons aloud at Firstborn meetings. This model derives from the structure of the meetings in prayer houses in early Laestadianism (Raittila 1984: 207). Currently, local preachers have 'spiritual tasks' (Kettunen 2017: 272) alongside their daily work, but the Firstborn also have senior or leading preachers called lähetys miehet (Raudaskoski 2014b) serving as speakers at national meetings. In addition, some of the leading preachers in Finland represent the Finnish branch at Firstborn Laestadian annual meetings in Sweden at Christmas in Gällivare and at Pentecost in Kiruna (Ihonen 2001: 169).

The appointment of new preachers by Firstborn Laestadians 'is in principle a matter for the local congregation' (Raittila 1984: 207; see also Nordvik 2013a: 122). However, Markku Ihonen (2001: 169) adds that while local supporters are heard, the preachers have the decisive role in this process, and the leading preachers supervise the appointment of new preachers. In 2016, a letter from the Firstborn's spiritual leaders affirmed this practice, saying 'God's congregation calls local workers', but the task was not only to preach, but to also administer the sacraments (Rauhan Side, 4, 2016: 12). This practice of appointing or electing preachers, as well as the meaning of the term preacher, seems to be part of the controversy between Firstborn Laestadians in Finland and the ELCF.

I assume that Firstborn Laestadians in 
Finland started administering the sacraments by themselves because they determined that it was a case of necessity. In interviews, representatives of the Firstborn in Finland expressed criticism of the ELCF on many issues: the ELCF's secularisation, a lack of trust in The

Lutheran Confessions, the false meaning of the Lord's Supper in the new liturgical handbook (brought out in the year 2000), the existence of female ministers and the lack of male minsters that could serve the Firstborn (Raudaskoski 2014a: 4; Raudaskoski 2014b; Seppälä 2015). In addition to these reasons, since the late 1990s Rauhan Side has also contained other critical remarks concerning, for example,
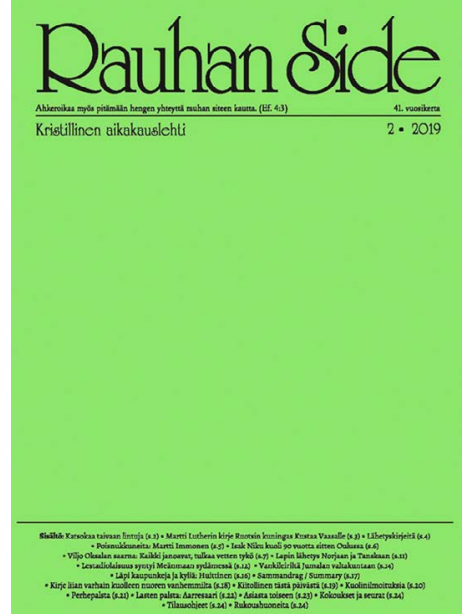

Cover of Rauhan Side, 2, 2019.
Side, 3, 2016: 18). According to the leading preachers, it is contrary to the Bible and The Lutheran Confessions that only an ordained - even a non-reborn - minister can distribute the sacraments. The letter also argued that Luther in his letter to the Bohemian brothers allowed lay people to administer the sacraments.

The regulations of both Firstborn Laestadians in Finland and the ELCF acknowledges The Lutheran Confessions as the authoritative document (see above; KL 1:1; KJ 1:1). Article 14 in The Augsburg Confession (AC) states: 'no one should publicly teach, preach, or administer the Sacraments without a proper calling' (AC 14). How does AC 14 relate to the conflict between Firstborn progress in ecumenical dialogues between Lutherans and Catholics and the ELCF's changed attitude towards homosexuality (see Rauhan Side, 1, 1995: 3-4, 11-12; 4, 1996: 4; 3, 1997: 8; 2, 1998: $3,11-12$; 1, 2001: 12-14; 3, 2016: 17-18). Outside of Finland, similar issues were subject to criticism by Firstborn Laestadians before they started administering the sacraments (e.g. Nordvik 2013a: 111, 118-19; Nordvik 2013b: 42-3, 53-5; SHBA, Letter from Laestadianerne, 31.3.2001; Elworth 2000: 4; Tervonen 2001: 7).

In February 2016, leading preachers sent a letter to the Ingrian Church which was published the same year by the Esikoislestadiolaiset Association in a shortened version (Rauhan Side, 3, 2016: 17-18). The first part of the letter repeats most of above-mentioned criticism towards the ELCF, while the latter part concerns the administration of the sacraments (Rauhan
Laestadians in Finland and the ELCF? In the summer of 2014, the Firstborn in Finland established a working group, whose task was to consider the administration of the sacraments at the Firstborn's own prayer houses (Raudaskoski 2014a: 4). As soon as this was publicly known and even after the Firstborn's first celebration of the Lord's Supper in December 2015, many of the ELCF's bishops stated that a proper calling according to $\mathrm{AC} 14$ is required for the administration of the sacraments (e.g. Häkkinen 2016a, 2016b; Jolkkonen 2016; for further statements see Rytkönen 2015a and Ijäs 2014). In December 2015, the chairman of the Firstborn Laestadians in Finland, Seppo Karhu, responded to the bishops' remark in an interview: 'Our servants of the word, who administer the Lord's Suppers, are called to their task. That's why they can distribute the Lord's Supper' 
(quote from Rytkönen 2015c). In addition, the scholar Teemu Kakkuri confirms the Firstborn Laestadians' own understanding of the ministry: 'In their community the authorised preachers represent the ministry. For this they have authorisation and the Holy Spirit has been given' (quote from Rytkönen 2015b). Thus, the controversy between the Firstborn in Finland and the ELCF concerns different interpretations of AC 14 and, as a consequence of this, also what the ministry is. The proper calling for the Firstborn in Finland is the same as appointing or electing preachers; that is to say, ordination is not an essential part of the proper calling. Nevertheless, the controversy also concerns issues such as who or what empowers the preachers and what are the preachers' jurisdictions.

These differing views on AC 14 between the Firstborn Laestadians and the ELCF are part of a broader controversy. Since the nineteenth century, scholars in Lutheran theology have argued about the nature of the ministry and how it is mediated according to The Lutheran Confessions and Luther's works. The interpretation of the expression 'proper calling' (Lat. nisi rite vocatus, Ger. ohn ordentlichen Beruf, BELK 1960: 69) in AC 14 is a part of this disagreement. Some scholars hold that AC 14 is referring to ordination and that ordination (with prayers and the laying on of hands) is essential to mediate the office of the ministry. Other scholars argue that a proper calling is identical with the congregation's election, and that the ordination is redundant since it only confirms the election. Furthermore, a few scholars claim that AC 14 and AC 5 concern the priesthood of all believers, not the office of the ministry (Ollilainen 2018: 223-32).

Is the Firstborn's argument in contradiction to The Lutheran Confessions and Luther's teaching? At least that is what the
ELCF's Bishop Jari Jolkkonen (2016) has claimed. I partly agree with Jolkkonen; however, as I said in the previous passage, the answer depends to a certain degree on the interpretation of The Lutheran Confessions (AC 5, 7, 14). What about Luther's teaching then? In the schism between the Firstborn and the ELCF, Luther's pastoral letter to the Bohemian brothers has been mentioned. For example, the preacher Odd Minde (2016) and the letter to the Ingrian Church (Rauhan Side, 3, 2016: 18) refer to Luther's letter, saying that he endorsed the administration of the sacraments by lay people. Jolkkonen (2016) dismissed this idea in his public letter to Firstborn Laestadians. I will now explain why Minde's conclusion about Luther's support for the administering of the sacraments by lay people is not entirely correct.

In Luther's pastoral letter, published in 1523 with the title De instituendis ministris ecclesiae, he evaluated the situation of the Bohemians as a case of necessity. Because only non-Christian and ungodly priests were available and the ordination by the Roman Catholic Church initiated the priest to perform blasphemy (i.e. the Mass), Luther suggested that the father of the household should baptise and teach God's word since the gospel and baptism are necessary for salvation. However, concerning the Lord's Supper, Luther said it is not necessary for salvation and therefore the Bohemian Christians should rather wait for God's intervention to send worthy priests, or, the congregations could use their right and power to dismiss unworthy priests. To conclude this matter, if necessary, and even during a longer period, lay people can administer the baptism, but Luther did not include the Lord's Supper in such cases of necessity (WA 12: 172-3).

Did Luther in his pastoral letter of the 1520 disavow the office of the ministry 
with the idea of a priesthood of all believers? Not at all. Luther's main point was that shaving a tonsure and anointing one's head with oil did not make anyone a priest or minister. Instead, every Christian by baptism in water and of the Spirit, that is to say, reborn of the Holy Spirit in baptism with water, has become a priest (WA 12: 178-9, 191). Luther emphasised seven functions or tasks of these priests (in the priesthood of all believers) that are the same for the office of the ministry. At the same time, and this is often misunderstood, Luther affirmed the existence of the ministry. Thus, Luther made a distinction, but not a separation, between the ministry and the priesthood of all believers. According to Luther, a worthy candidate was to be elected by the congregation and entrusted to the office of the ministry by ordination. The ordination was based on the authority of the Bible and in accordance with the Apostles' example and instructions. Thus, the proper way to initiate new ministers included ordination and was not purely limited to the election by the congregation (WA 12: 193-4). Later in the 1530s, Luther put more emphasis on the Church's ministry due to the uprising of the Enthusiasts (Öberg 1970: 367-8).

As a final point about Luther, Bernhard Lohse (1995: 307) remarks that in Luther's writings it is of great importance to distinguish between emergency conditions and normal conditions. The latter case clarifies Luther's actual position. In the 1530 s when the order of the Evangelical Church was beginning to take form, Luther barred Johann Sutel from administering the Holy Communion, even though the congregation had elected him, because Sutel was not ordained (Smith 2000: 63-4). Luther certainly preferred that only those appointed with ordination should distribute the Lord's Supper. Thus, Firstborn Laestadianism's point of view differs from
Luther's teaching in two ways. Firstly, the initiation to the priesthood of all believers, according to Luther, is by rebirth in baptism (in water) and that participation in this priesthood is preserved by faith. Secondly, Firstborn Laestadianism lacks Luther's terminological and theological distinction between priests (as referring to the members of the priesthood of all believers) and the ministers (as referring to those who, for example, preach and administer the sacraments privately and publicly). As I have shown, both concepts were not identical for Luther. Through baptism and faith, every Christian is a priest, as in the priesthood of all believers; however, that does not mean that every Christian occupies the office of the ministry or can be called a minister (Öberg 1984: 63-6).

Laestadius was not concerned with traditional questions about the office of the ministry such as, for example, the nature or the basis of the ministry. According to Hannu Juntunen, since Laestadius did not reject the ministry he probably accepted the existence of it. Instead, Laestadius emphasised the aim of all preaching and teaching: to guide people in ordo salutis, foremost to an experienced contrition and reconciliation culminating in rebirth. Laestadius criticised his contemporary clergy for lacking their own experiences in ordo salutis; hence, they could not lead others to experience the same. The clergy's main error was their preaching of God's mercy to nonpenitent listeners, and that their preaching did not strive for a felt contrition (Juntunen 1982: 154-165; about Laestadius's pastoral counselling, see Leivo 2001). Lilly-Anne Østtveit Elgvin (2010: 321-5) has underscored the practical side of Laestadius's understanding of the office of the ministry. Laestadius used the terms 'sheepfold' and 'sheep barn' as metaphors for the Church in his sermons; consequently, a pastor should 
be like a good sheepdog, who watches over the sheep (true believers) and separates them from the goats (non- or false believers).

\section{Conclusions}

In this article, I have investigated two doctrinal concepts mediated within FBL. By looking into the concept of the priesthood of all believers and that of the preacher, it is possible to give a plausible explanation as to why Firstborn Laestadians in Finland started administering the sacraments themselves.

The concept of the priesthood of all believers actualises at least two essential matters. Firstly, it is not possible to conclude a clear consensus in terminology, but with regard to my examples it seems that the Firstborn recognise only the priesthood of all believers. The basis for this priesthood is rebirth. Therefore, Firstborn Laestadians do not recognise ELCF's ordained ministers as genuine ministers since nothing external like ordination can differentiate them from Firstborn preachers. This reasoning is reminiscent of a conflict which occurred in Laestadianism in the USA during the 1870 os and 8os. According to Tuomas Palola (2014: 31-114), different factions during this period supported ministers who had studied theology and who were ordained (referred to as virkapappeus) or lay persons functioning as ministers with little or no theological training (referred to as maalikkopappeus). An idiomatic translation is tricky; I would suggest 'official ministry' and 'lay ministry'. Currently, Firstborn preachers in the USA (OALC) have no theological education, ordination or blessing that initiates them into their work (Kettunen 2017: 273). In this respect, the OALC and the Firstborn in Finland seem to agree and, according to Jouko Talonen, the new practice of the preachers in the Firstborn in Finland comes from the OALC (interview in Kurvinen 2016; see also Kettunen 2017: 273). However, more research is required on the impact of this interpretation of the priesthood of all believers when the Firstborn began administering the sacraments by themselves. At least some Firstborn preachers used the concept of the priesthood of all believers to support the commencement of preachers within the movement administering the sacraments.

Secondly, a cornerstone in Firstborn Laestadianism's ecclesiology is the idea that the priesthood of all believers is connected with the power of the keys. Together they result in an exclusive ecclesiology. However, if, according to FBL the keys belong to all reborn believers, then why was the same reasoning not applied to baptism much earlier? Did not Jesus' disciples, who received the keys (John 20:22-3), also get the Great Commission, including baptism (Matt. 28:18-20)? Consequently, if Firstborn Laestadians represent the true believers, or the only true Christianity in the world; if the movement occupies the power of the keys, then it is very logical that Firstborn Laestadians would start administering the sacraments on their own. It seems unlikely, with such an exclusive ecclesiology and an interpretation of the ELCF's ministers as false, that any argument could have persuaded Firstborn Laestadians to continue to delegate administration of the sacraments to the ELCF.

The Firstborn Laestadians' earlier separation of the power of the keys and administering the sacraments seems in the current situation to be in some way peculiar or inconsistent. If earlier preachers could preach the gospel publicly and give absolution but not administer the sacraments, then something must have motivated expanding the jurisdictions of the preacher. It seems 
that the origin for the Nordic countries' tradition of limiting the preacher's jurisdiction was in doctrinal arguments; however, the doctrine of the preacher was adapted to fit the historical circumstance when lay people were not allowed to administer the Lord's Supper. But can that doctrine be further developed? That seems to be what has happened recently.

The concept of the preacher highlights how a man becomes a preacher by first being a reader. One prerequisite for becoming a preacher is rebirth, whereas the initiation to the preaching task is through some kind of election by the Firstborn's local congregation, but effectively the leading preachers are in charge of the process. Very likely, this action is not comparable to an ordination (which includes prayer and the laying on of hands).

Firstborn Laestadians in Finland associated with the Esikoislestadiolaiset Association seem to interpret the concept of preacher in the same way as the ELCF understands the office of the ministry; that is, with the same power of jurisdiction to preach, absolve, baptise and administer the Lord's Supper. Considering the current practice among the Firstborn in Finland this assumption is confirmed. The aforementioned concepts used in the OALC (virkapappeus and maalikkopappeus) is another example of how the power of jurisdiction can be all the same. That is to say, there is at least no longer an essential difference between an elected preacher and an ordained minister.

My last point is that the use of language and terminology is one part of the schism between the Firstborn in Finland and the ELCF. In everyday language and in a general Christian context, the English word for 'priest' is präst in Swedish and pappi in Finnish. These words primarily refer to the office of the ministry. One factor in the confusion might be the term in the Finnish Bible translations of 1 Peter 2:5 and 2:9, which uses the expression papisto (Raamattu 1932/8; Raamattu 1992) as in 'priesthood'. From these Bible passages, and the Book of Revelation 1:6 and 5:10, Luther derived his idea of the priesthood of all believers (Lieberg 1962: 40-3; Stein 1974: 63-7, 85, 124-30; Öberg 1984: 60-2). Still, Luther made a distinction between priests (Lat. sacerdotium) as in the priesthood of all believers based on baptism and faith, and on the other hand, ministers (Lat. ministerium) as in the office of the ministry based on baptism and mediated through ordination (Ollilainen 2018: 223-32). If this distinction or essential difference is not known, made or kept, then it will probably lead to a mix-up between the priesthood of all believers and the ministry. This seems to be one reason why Firstborn Laestadians in Finland started to administer the sacraments.

\section{Anssi Ollilainen,}

Dr.Theol., is Deputy University Teacher in Dogmatics since September 2017 at the Faculty of Arts, Psychoogy and Theology at the Ábo Akademi University in Turku, Finland. His research interests are historical

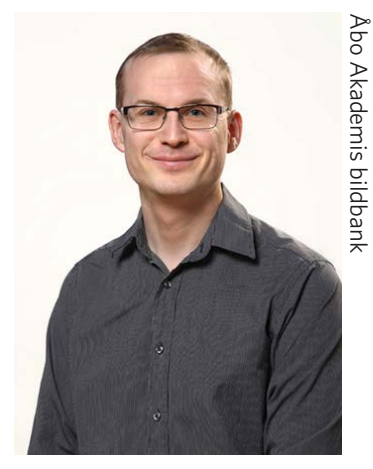
and temporary ideas on ecclesiology and theology of the ministry within churches and Christians movements. Ollilainen's main publications are the two editions of his doctoral thesis published in 2017 and 2018. 


\section{References}

\section{Archive sources}

Esikoislestadiolaiset ry, 2 \$: Yhdistyksen tarkoitus (Purpose of the association), Finnish Patent and Registration Office

SHBA = Sør-Hålogaland biskops arkiv, Bodø

Laestadianerne - Den opprinnelige apostoliske-lutherske forstefødtes församling

Letter from Laestadianerne - Den opprinnelige apostoliske-lutherske forstefødtes församling to Bispekollegiet, Den norske kirke 31.3.2001 (copy)

\section{Other sources}

Aaltonen, Matti, 1998. 'Herra on lähettänyt parantamaan särjettyjä sydämiä. Matti Aaltosen saarna Tampereella 25.4.1994', in Rauhan Side, 2o(3), pp. 5-9

$\mathrm{AC}=$ The Augsburg Confession (1530), in The Book of Concord: The Confessions of the Evangelical Lutheran Church, eds. Robert Kolb and Timothy J. Wengert (Minneapolis, Fortress Press, 2010)

Airamo, Raimo, 2007. 'Syntisen kohtaaminen', in Rauhan Side, 29(3), p. 2

-_-2012. 'Evankeliumin asialla', in Rauhan Side, 34(3), p. 2

BELK = Die Bekenntnisschriften der evangelischlutherischen Kirche, 5. unveränderte Auflage (Berlin, Evangelische Verlagsanstalt, 1960)

Häkkinen, Seppo, 2016a. 'Mikkelin hiippakunnan seurakuntien kirkkoherroille', letter dated 7.1.2016, <https://storage.googleapis.com/piispat-production/2018/04/esikoislestadiolaisten-ehtoollisen-vietto.pdf> (accessed 6.9.2019)

_-_ 2016b. 'Mikkelin hiippakunnan seurakuntien kirkkoherroille, letter dated 7.9.2016, $<$ https://storage.googleapis.com/piispatproduction/2018/04/esikoislestadiolaisetkast-kirje-kirkkoherroille-7.9.2016.pdf> (accessed 6.9.2019)

Jolkkonen, Jari, 2016. 'Avoin kirje sisarille ja veljille esikoislestadiolaisessa herätysliikkeessä, letter from the Bishop of Kuopio 24.4.2016, diocese<https://docplayer.fi/23592922Kuopion-hiippakunnan-piispa.html> (accessed 6.9.2019)

KJ = Kirkkojärjestys (Church order, 8.11.1991/ 1055 v. 1993). '1 luku: Kirkon tunnustus ja jäsenet', <https://www.finlex.fi/fi/laki/ajantasa/1993/19931055> (accessed 7.9.2019)
$\mathrm{KL}=$ Kirkkolaki (Church law, 26.11.1993/1054). '1 luku: Kirkon tunnustus, tehtävä ja jäsenet', <https://www.finlex.fi/fi/laki/ajantas a/1993/19931054\#a1054-1993> (accessed 7.9.2019)

Larsson, Lars, 2012. 'Vaatteet on pesty Karitsan veressä. Lars Larssonin saarna Kiirunan kirkossa 12.6.2011', in Rauhan Side, 34(3), pp. $5^{-8}$

- - 2016. 'Jumala rakastaa kadonnutta penninkiä ja tuhlaajapoikaa', in Rauhan Side, 38(2), pp. 5-10

Liuksala, Pekka, 1996. 'Ylösnousseen Vapahtajan lähettiläinä, in Rauhan Side, 18(2), p. 2

Minde, Odd, 2016. 'Odd Minden saarna 26.12.2015 Jellivaaran iltaseuroista', Sakramenttiyhteys website, <http://www. sakramentit.fi/wordpress/wp-content/ uploads/2016/o1/Odd-Minde-26-Joulukuu-2015-ilta.pdf $>$ (accessed 5.9.2019)

Nousiainen, Eino, 2009. 'Mitään kadotustuomioita ei ole niille, jotka ovat Kristuksessa Jeesuksessa', in Rauhan Side, 31(3), pp. 5-8

Raamattu, 1932/8. Vanha Testamentti - XI yleisen Kirkolliskokouksen vuonna 1933 käytäntöön ottama suomennos. Uusi Testamentti - XII yleisen Kirkolliskokouksen vuonna 1938 käytäntöön ottama suomennos (Helsinki, Suomen Pipliaseura)

- - 1992. Suomen evankelisluterilaisen kirkon kirkolliskokouksen vuonna 1992 käyttöön ottama suomennos (Kirjapaja, Suomen Kirkon Sisälähetysseura)

Rauhan Side, 1, 1995; 31(4), 2009; 3 and 4, 2016 Usko on sydämen asia (Lahti, Esikoislestadiolaiset ry, 2014)

WA = Weimar Ausgabe, D. Martin Luther's Werke. Kritische Gesamtausgabe: Schriften, 12. Band (Weimar, H. Böhlau, 1891)

\section{Bibliography}

Aadnanes, Per, 1986. Laestadianismen i NordNorge (Oslo, Tano)

Airamo, Raimo, and Seppo Leivo, 1983. Esikoislestadiolaisuus Lahdessa ja sen ympäristössä, erikoispainos Päijät-Hämeen tutkimusseuran vuosikirjasta 1983 (Lahti, ABC)

Airikka, Kirsi, 2017. 'Esikoiset löysivät kodin', in Silta, 10 (2017), pp. 12-13, <http:// view. $24 \mathrm{mags.com} / \mathrm{mobilev} / \mathrm{b} 1 \mathrm{e} 37 \mathrm{~d} 2 \mathrm{c}$ coo34beea $189 \mathrm{f} 29555 \mathrm{f} 9 \mathrm{c} 1 \mathrm{~d} 7 \# /$ page $=1>$ (accessed 5.9.2019) 
Berg, Antti, 2016. 'Mitä esikoislestadiolaisille tapahtui? Kotimaa käy läpi eron vaihe vaiheelta', in Kotimaa24, 20.8.2016, <https:// www.kotimaa24.fi/artikkeli/mita-esikoislestadiolaisille-tapahtui-kotimaa-kay-lapieron-vaihe-vaiheelta> (accessed 6.9.2019)

Blom, Risto, 2001. Jumalan lapseksi. Käsitys uudestisyntymisestä esikoislestadiolaisessa julistuksessa (Tampere, Kirkon tutkimuskeskus)

Bolle, Roald, 2000. 'Læstadianismen i det moderne samfunn', in Vekkelse og vitenskap: Lars Levi Laestadius 200 år, eds. Øyvind Norderval and Sigmund Nesset (Tromsø, Ravnetrykk), pp. 138-56

Elworth, Kerstin, 2000. 'De vill döpa utan präst', in Kyrkans tidning, 19(48), p. 4

Gassmann, Günther, and Scott Hendrix, 1999. Fortress Introduction to the Lutheran Confessions (Minneapolis, Fortress Press)

Grenholm, Carl-Henric, 2006. Att förstå religion. Metoder för teologisk forskning (Lund, Studentlitteratur)

Hintsala, Meri-Anna, and Mauri Kinnunen (eds.), 2013. Tuoreet oksat viinipuussa. Vanhoillislestadiolaisuus peilissä (Helsinki, Kirjapaja)

Huhta, Ilkka, 2001. 'Täällä on oikea Suomenkansa'. Körttiläisyyden julkisuuskuva 18801918, PhD dissertation (University of Helsinki)

Hurtig, Johanna, 2013. Taivaan taimet. Uskonnollinen yhteisöllisyys ja väkivalta (Tampere, Vastapaino)

Hytönen, Maarit, and Leena Sorsa, 2016. 'Kirkko julkisena keskustelijana', in Osallistuva luterilaisuus. Suomen evankelis-luterilainen kirkko vuosina 2012-2015: Tutkimus kirkosta ja suomalaista, eds. Kimmo Ketola et al. (Tampere, Kirkon tutkimuskeskus), pp. 222-50

Ihonen, Markku, 2001. 'Esimodernista myöhäismoderniin. Esikoislestadiolaisuus kohtaa nykymaailman', in Lestadiolaisuuden monet kasvot, eds. Ilpo Harjutsalo and Jouko Talonen (Helsinki, Suomen teologinen instituutti), pp. 154-76

Ijäs, Johannes, 2014. “"Vakava toive”. Kotimaa24 julkaisee piispojen viestin esikoislestadiolaisille, in Kotimaa24, 5.11.2014, <https://www.kotimaa24.fi/artikkeli/ vakava-toive-kotimaa24-julkaisee-piispojen-viestin-esikoislestadiolaisille> (accessed 6.9.2019)
Juntunen, Hannu, 1982. Lars Levi Laestadiuksen käsitys kirkosta, $\mathrm{PhD}$ dissertation (University of Helsinki)

Kettunen, Ville, 2016. 'Jumalan rakkauden ruoska. Lain käyttö Isän ääni -lehdessä', unpublished master's thesis (University of Helsinki)

-_-2017. 'Esikoislestadiolaisuuden sakramenttiseparatismi ja jakautuminen', in Perusta, 44(5), pp. 272-7

Kurvinen, Virpi, 2016. 'Kiista sakramenteista jakaa esikoislestadiolaisia, in Uusi Tie, 2.2.2016, <https://uusitie.com/kiistasakramenteista-jakaa-esikoislestadiolaisia $>$ (accessed 9.9.2019)

Lahtinen, Antti, 1984. 'Esikoislestadiolaisuuden syntyvaihe Suomessa vuoteen 1911', unpublished master's thesis (University of Helsinki)

Leivo, Seppo, 2001. 'Jeesuksen nimessä ja veressä. Synninpäästön käyttöönotto lestadiolaisuudessa', in Lestadiolaisuuden monet kasvot, eds. Ilpo Harjutsalo and Jouko Talonen (Helsinki, Suomen teologinen instituutti), pp. 103-21

Lieberg, Hellmut, 1962. Amt und Ordination bei Luther und Melanchthon (Göttingen, Vandenhoeck \& Ruprecht)

Linjakumpu, Aini, 2018. Vanhoillislestadiolaisuuden taloudelliset verkostot (Tampere, Vastapaino)

Lohi, Seppo, 1997. Pohjolan kristillisyys. Lestadiolaisuuden leviäminen Suomessa 18701899, PhD dissertation (University of Oulu)

- - 2007. Lestadiolaisuuden suuri hajaannus ja sen taustat (Oulu, Suomen Rauhanyhdistysten Keskusyhdistys)

Lohse, Bernhard, 1995. Luthers Theologie in ihrer historischen Entwicklung und ihrem systematischen Zusammenhang (Göttingen, Vandenhoeck \& Ruprecht)

Nordvik, Torgeir, 2013a. 'Protestbevegelse eller nytt kirkesamfunn? De førstefødte læstadianere tar sakramentene i egne hender', in Din. Tidsskrift for religion og kultur, (2), pp. 108-28, <http://ojs.novus.no/index. php/DIN/article/view/799/794> (accessed 5.9.2019)

_-—2013b. 'Åpen og inkluderende. Kirkelig strategi mellom makt og avmakt', in Teologisk Tidsskrift, 2(1), pp. 41-61

-_-2015. Latadianerne og kirken. De førstefødtes og Lyngen-retningens forhold til Den 
norske kirke ved inngangen til 2000-tallet, $\mathrm{PhD}$ dissertation (The Arctic University of Norway), <https://hdl.handle. net/10037/7794> (accessed 6.9.2019)

Numminen, Leena, 2000. 'Perinteen puolustajat muutospaineessa. Esikoislestadiolaisen herätysliikkeen sukupuoliroolit muutosprosessin heijastajina, unpublished master's thesis (University of Helsinki)

Öberg, Ingemar, 1970. Himmelrikets nycklar och kyrklig bot i Luthers teologi 1517-1537, PhD dissertation (Uppsala University)

_- - 1984. 'Den lutherska reformationen och ordinationen', in Så tilholder og formaner jeg deg. En studiebok om ordinasjon/vigsling til kirkelig tjeneste, eds. Arne J. Eriksen and Helge Aarflot (Oslo, Den Norske kirkes presteforening), pp. 59-86

Ollilainen, Anssi, 2018. Bo Giertz om prästämbetet. Uppdragets teologi $[\mathrm{PhD}$ dissertation, Åbo Akademi University], 2nd rev. edn (Skellefteå, Artos \& Norma bokförlag)

Østtveit Elgvin, Lilly-Anne, 2010. Lars Levi Lostadius' spiritualitet, $\mathrm{PhD}$ dissertation (Uppsala University)

Palola, Tuomas, 2014. Amerikkalainen vai pohjoismainen? Amerikan apostolis-luterilaisuus 1884-1929, PhD dissertation (University of Helsinki)

Raittila, Pekka, 1984. 'Esikoislestadiolaisuus Suomessa, in Suomen kirkkohistoriallisen seuran vuosikirja, 74, pp. 190-225

Raudaskoski, Joona, 2014a. 'Esikoislestadiolaiset pohtivat sakramenttien ottamista omiin käsiin', in Kotimaa, 109(31), p. 4

- - 2014b. 'Esikoislestadiolaiset vastustavat liikkeen omia sakramentteja adressilla', Kotimaa24, 22.10.2014, <https://www.kotimaa24.fi/artikkeli/esikoislestadiolaisetvastustavat-liikkeen-omia-sakramenttejaadressilla> (accessed 9.9.2019)

Rytkönen, Jussi, 2015a. 'Esikoislestadiolaisten ehtoollisirtiotto todeksi', in Kotimaa, $110(49)$, pp. 6-7

- _ 2015b. 'Herätysliiketutkija: Esikoislestadiolaisten irtiotto on kirkkohistoriallinen', Kotimaa24, 8.12.2015, <https://www.kotimaa24.fi/artikkeli/heratysliiketutkija-esikoislestadiolaisten-irtiotto-on-kirkkohistoriallinen> (accessed 6.9.2019)

- - 2015c. 'Esikoislestadiolaiset: "Ehtoollinen ei ole luterilaisen kirkon monopoli", in Kotimaa24, 17.12.2015, <https://www. kotimaa24.fi/artikkeli/esikoislestadiolaiset-ehtoollinen-ei-ole-luterilaisen-kirkonmonopoli> (accessed 6.9.2019)

- - 2016a. 'Esikoislestadiolaiset maallikot kastavat nyt lapsia', in Kotimaa24, 21.1.2016, $<$ https://www.kotimaa24.fi/artikkeli/esikoislestadiolaiset-maallikot-kastavat-nytlapsia> (accessed 6.9.2019)

- - 2016b. 'Esikoislestadiolainen herätysliike pelkää jakautumista, in Kotimaa24, 3.5.2016, <https://www.kotimaa24.fi/artikkeli/esikoislestadiolainen-heratysliike-pelkaa-jakautumista $>$ (accessed 6.9.2019)

- - 2016c. 'Uusi yhdistys perustettu. Esikoislestadiolainen herätysliike jakautuu', in Kotimaa24, 15.8.2016, <https://www.kotimaa24.fi/artikkeli/uusi-yhdistys-perustettu-esikoislestadiolainen-heratysliikejakautuu $>$ (accessed 6.9.2019)

Seppälä, Olli, 2015. '"Etenemme kohti sakramenttien ottamista omaan käyttöön", in Kotimaa24, 13.10.2015, <https://www. kotimaa24.fi/artikkeli/etenemme-kohtisakramenttien-ottamista-omaan-kayttoon> (accessed 6.9.2019)

Sivertsen, Dagmar, 1955. Lostadianismen $i$ Norge, PhD dissertation (University of Oslo)

Smith, Ralph F., 2000. Luther, Ministry, and Ordination Rites in the Early Reformation Church (New York, Peter Lang)

Snellman, Gerd, 2011. Sions döttrar. De laestadianska kvinnorna som traditionsförmedlare i norra svenska Österbotten åren 1927-2009, PhD dissertation (Åbo Akademi University) Stein, Wolfgang, 1974. Das kirchliche Amt bei Luther (Wiesbaden, F. Steiner)

Talonen, Jouko, 1993. Esikoislestadiolaisuus ja suomalainen yhteiskunta 1900-1944 (Helsinki, Suomen kirkkohistoriallinen seura)

- - 2000a. 'Laestadianismen i Finland', in Laestadius 200 år, eds. Sölve Anderzén, Jouko Talonen, Lilly-Anne Østtveit Elgvin and Trygve Paulsen (Alta, Høgskolen i Finnmark), pp. 37-51

- - 20oob. 'Laestadianism in an international perspective', in Laestadius 200 år, eds. Sölve Anderzén, Jouko Talonen, Lilly-Anne Østtveit Elgvin and Trygve Paulsen (Alta, Høgskolen i Finnmark), pp. 53-9

- - 2013. 'Laestadius ja lestadiolaisuus Baltiassa', in Opin poluilla. Juhlakirja Miikka Ruokasen täyttäessä 60 vuotta, eds. Tiina 
Ahonen, Jyri Komulainen and Mika Vähäkangas (Helsinki, Suomen Teologinen Kirjallisuusseura), pp. 19-62

- - 2014. 'Lestadiolaisuuden synty, leviäminen ja hajaannukset', in Teologinen Aikakauskirja, 119(3), pp. 19-34

-2016. 'Lestadiolaisuus muuttuvan ajan paineissa', in Perusta, 42(3), pp. 133-46

Tervonen, Heikki, 2001. 'Vastalause Ruotsin kirkon maallistumista vastaan. Lestadiolaiset ryhtyivät jakamaan itse sakramentteja, in Kotimaa 96(10), p. 7

Zidbäck, Aulis, 1941. Pohjolan suurin maallikkosaarnaaja. Juhani Raattamaan kristillisyydennäkemys ja suhde laestadiolaisuuden suuntamuodostukseen. Kysymys 'esikoisseurakunnasta' (Helsinki, Otava) 